\section{Growth and Yield of Organic Day- neutral Strawberries in Low Tunnels inside High Tunnel in North Carolina}

\author{
Tekan S. Rana and Sanjun Gu \\ Cooperative Extension Program, North Carolina Agricultural and Technical \\ State University, 1601 E. Market Street, Greensboro, NC 27411
} Additional index words. 'Albion', biomass, Fragaria $\times$ ananassa, harvest index, planting date,
'San Andreas', season extension

\begin{abstract}
North Carolina's fresh strawberry has a \$21.4 million economic value, which is primarily from short-day cultivars in the annual plasticulture system. Organic and offseason day-neutral strawberries have higher prices than the conventional, field-grown strawberries. There have been no published studies on suitable cultivars, transplanting dates, and additional winter protection methods for day-neutral strawberry production in high tunnels in North Carolina. The objective of this study was to examine the effect of low tunnels, planting dates, and cultivars on growth, yield, and season extension potential of day-neutral strawberries in high tunnels. Plugs of day-neutral cultivars Albion and San Andreas were either transplanted in raised beds covered with low tunnels (LT) or without low tunnels (control, NLT), inside high tunnels on the N.C. A\&T State University Farm (Greensboro, NC) on two different planting dates, which were 1 Sept. (D1) and 29 Sept. (D2) of 2016, or 9 Sept. (D1) and 10 Oct. (D2) of 2017, respectively. A completely randomized design with split-split plots was used. LT did not significantly affect the total yield and plant phenology, but they promoted the first harvest by a week compared with NLT, which resulted in higher yield during the winter of both years. D1 promoted about 24 days of earlier harvest than D2. 'Albion' had an earlier bloom and harvest date (by 1 to 3 weeks and 2 to 3 weeks, respectively) than 'San Andreas'. Strawberry yield was low in the fall season, but it started to increase from January, peaked in April, and decreased again in May. D1 increased the whole season's marketable yield of 'Albion' (430.3 g/plant), compared with that of 'San Andreas' (330.9 g/plant). During the winter, 'Albion' had a higher yield than 'San Andreas'. Our study indicates that LT inside HT might not significantly improve the plant growth, early harvest, or total yield. Planting dates had no consistent effect on yield. It was suggested that 'Albion' should be considered for high winter yields, and 'San Andreas' be a cultivar with high yields of the entire season in high tunnels.
\end{abstract}

With an economic value of $\$ 3.5$ billion, strawberry (Fragaria ×ananassa Duch.) is among the top five most economically important fresh market fruits (Lewers et al., 2017; Rowley et al., 2011). North Carolina ranked third in the nation for its total strawberry production of 1100 acres and an economic

Received for publication 7 Oct. 2019. Accepted for publication 16 Dec. 2019.

Published online 6 February 2020.

This project was supported by the United States Department of Agriculture's NIFA Evans-Allen project NC.X-301-5-16-130-1 and OREI project 2015-51300-24134.

We thank John E. Beck, John E. Kimes, and other staff members of the Extension Horticulture Unit for the help in crop management and data collection.

Current address for T.S.R.: Horticulture Science, North Carolina State University, Kilgore Hall 227, Box 7609, Raleigh, NC 27695.

T.S.R. is a Graduate Research Assistant.

S.G. is the corresponding author. E-mail: sgu@ ncat.edu.

This is an open access article distributed under the CC BY-NC-ND license (https://creativecommons. org/licenses/by-nc-nd/4.0/). such as tomatoes, lettuce, small fruits, cut flowers, and herbs (Bumgarner et al., 2012; Carey et al., 2009; Lamont, 2009; Orzolek et al., 2004; Rogers and Wszelaki, 2012). Various studies on HT strawberry production (Kadir et al., 2006; Rowley et al., 2010, 2011; Vocìa et al., 2007; Xiao et al., 2001) have shown HT to increase yield and fruit quality, and to extend harvest time up to 5 weeks, compared with open field strawberry production. HT generally maintain higher minimum temperatures during winter (Bomford et al., 2007; Gu et al., 2017a; Wien, 2009; Xiao et al., 2001; Zhao and Carey, 2009). Most of these studies used June-bearing cultivars. Our previous varietal trials also proved that, with the help of rowcovers, strawberry could be successfully produced through winter, although unpredictable low temperatures in winter could cause chilling damage to fruit (Gu et al., 2017b). Additional winter protections such as adding low tunnels (LT) inside HT, may lead to reliable winter harvests.

A LT is a small-framed structure $(<0.75 \mathrm{~m}$ tall) covered by transparent plastic or nonwoven fibers over the plant canopy (Waterer, 2003). Although studies on LT microclimate and its effect on crop production are not as broad as that of HT, some studies have revealed that LT provides warmer temperatures during winter, protects crops from frost, and enhances crop yield (Enoch et al., 1970; Jenni et al., 2006; Lewers et al., 2017; Singh et al., 2012; Siwek et al., 2009; Waterer, 2003). LT are cheap and easy to construct, to relocate, to adjust on the covered area, and to reuse all parts but the plastic cover for following seasons (Anderson, 2018; Lewers et al., 2017).

While June-bearing strawberries have been a focus in HT, day-neutral strawberries also have their place. For day-neutral strawberries, photoperiod does not affect their flower initiation when temperature is below $10{ }^{\circ} \mathrm{C}$ (Sønsteby and Heide, 2007). However, temperature and photoperiod interaction would hugely impact the flowering response and day-neutrality of the day-neutral cultivars. They will flower when temperatures are between 4 to $29{ }^{\circ} \mathrm{C}$ (Rowley et al., 2011; Tabatabaie and Murthy, 2016), thus having the potential to extend harvest period that opens the window for off-season production (Reitmeier and Nonnecke, 1991). Dayneutral cultivar Albion in the annual plasticulture system can produce around $1 \mathrm{~kg} /$ plant marketable yield during a 6-month harvest period (from mid-May to mid-October) with better fruit quality than other day-neutral cultivars (Ballington et al., 2008). In Korea, the total yield of 'Albion' and 'San Andreas' was reported as 2.42 and $3.29 \mathrm{~kg} /$ plant, respectively (Ruan et al., 2011). Both cultivars have better fruit quality compared with other day-neutral cultivars and June-bearers (Ballington et al., 2008; Ruan et al., 2013; Tudor et al., 2014). In our pervious cultivar evaluations, 'Albion' and 'San Andreas' had earlier fruit harvest than June-bearers (Gu et al., 2017b).

Besides microclimate and cultivars, planting dates also affect strawberry yield and 
harvest period (Chandler et al., 1991). Different transplanting dates have different effects on strawberry yield depending upon locations and cultivars. 'Seascape' and other day-neutral cultivars have shown higher marketable yield with early-fall transplanting compared with late-fall transplanting ( 9 and 25 Sept., vs. 30 Oct.) in North Carolina (Ballington et al., 2008). In Kansas, 'Chandler' and 'Sweet Charlie' planted in midSeptember produced fruit 5 weeks earlier than those planted in mid-October (Kadir et al., 2006).

Agricultural products produced following USDA Organic Standards, such as without the use of synthetic pesticides, fertilizers, and hormones are regarded as organic (Esitken et al., 2010). The demand for organically produced strawberry is increasing in Europe and the United States (Reganold et al., 2010). The United States had around \$242 M in sales of organic strawberries from 611 certified

Table 1. Days after planting (DAP) for the first bloom, 50\% bloom, and the first harvest in 2016-17.

\begin{tabular}{|c|c|c|c|}
\hline Treatment & First bloom & $50 \%$ bloom & First harvest \\
\hline \multicolumn{4}{|c|}{ Protection methods (P) } \\
\hline $\mathrm{LT}^{\mathrm{z}}$ & 36 & 90 & 59 \\
\hline NLT & 35 & 91 & 65 \\
\hline \multicolumn{4}{|c|}{ Planting dates (D) } \\
\hline D1 & 40 & 128 & 60 \\
\hline D2 & 30 & 53 & 64 \\
\hline \multicolumn{4}{|l|}{ Cultivars (C) } \\
\hline Albion & 33 & 87 & 59 \\
\hline San Andreas & 37 & 94 & 65 \\
\hline \multicolumn{4}{|l|}{ Significance } \\
\hline $\mathrm{P}$ & NS & NS & NS \\
\hline $\mathrm{D}$ & 0.001 & $<0.0001$ & NS \\
\hline$P \times D$ & NS & NS & NS \\
\hline $\mathrm{C}$ & NS & NS & NS \\
\hline $\mathrm{P} \times \mathrm{C}$ & NS & NS & NS \\
\hline $\mathrm{D} \times \mathrm{C}$ & 0.0082 & NS & 0.031 \\
\hline $\mathrm{P} \times \mathrm{D} \times \mathrm{C}$ & NS & NS & NS \\
\hline
\end{tabular}

${ }_{\mathrm{z}}^{\mathrm{LT}}=$ low tunnels, NLT $=$ no low tunnels, D1 = 1 Sept., D2 = 29 Sept., DAP = days after planting, NS = not significant (at $P \geq 0.05$ ) per Fisher's least significant difference test.

Table 2. Simple effects of planting dates (D) and cultivars (C) for days after planting (DAP) of the first bloom and the first harvest in 2016-17.

\begin{tabular}{lccccc}
\hline \multirow{2}{*}{ Cultivars } & \multicolumn{2}{c}{ First bloom $\left(\mathrm{DAP}^{\mathrm{z}}\right)$} & & \multicolumn{2}{c}{ First harvest (DAP) } \\
\cline { 2 - 3 } \cline { 6 - 7 } & $\mathrm{D} 1$ & $\mathrm{D} 2$ & & $\mathrm{D} 1$ & $\mathrm{D} 2$ \\
\hline Albion & $42 \mathrm{a}^{\mathrm{y}}$ & $25 \mathrm{~b}$ & & $62 \mathrm{a}$ & $56 \mathrm{~b}$ \\
San Andreas & $\mathrm{a}^{\mathrm{x}}$ & $\mathrm{b}$ & & $\mathrm{a}$ & $\mathrm{a}$ \\
& $39 \mathrm{a}$ & $36 \mathrm{a}$ & & $59 \mathrm{a}$ & $72 \mathrm{a}$ \\
$\mathrm{D} \times \mathrm{C}(P$ value $)$ & $\mathrm{a}$ & $\mathrm{a}$ & & $\mathrm{b}$ & $\mathrm{b}$ \\
& 0.0082 & & & 0.031 &
\end{tabular}

${ }^{\mathrm{z}} \mathrm{DAP}=$ days after planting, D1 $=1$ Sept., D2 = 29 Sept.

${ }^{\mathrm{y}}$ Within each column of a category (first bloom or first harvest), values labeled with a different letter are significantly different $(P<0.05)$ per Fisher's least significant difference test for cultivars (Albion vs. San Andreas).

${ }^{\mathrm{x}}$ Within each row of a category (first bloom or first harvest), values with a same letter are not significantly different at the 5\% level per Fisher's least significant difference test for planting dates (D1 vs. D2).

farms in 2016. North Carolina had 10 certified organic strawberry farms on 12 acres of land with an economic value of $\$ 0.4 \mathrm{M}$ (USDA-NASS, 2017). Although an organic strawberry system may have low yields, various studies have reported higher berry quality (antioxidant activities, ascorbic acid content, phenolic compounds, and shelf life), compared with berries from the conventional system (Conti et al., 2014; Crecente-Campo et al., 2012; Khalil and Hassan, 2015). The better fruit quality and increasing demands on organic products may be the reasons for their higher price $(>\$ 4.05 / 1 \mathrm{~b})$ when compared with that of the conventionally grown $(\$ 2.87 / \mathrm{lb})$ (USDA-AMS, 2018).

Studies on plasticulture strawberry have been conducted mostly in the open field system. There are only a few studies on the effect of LT alone or of LT inside the HT that were concentrated on other high-value crops such as muskmelon, sweet pepper, spearmint, thyme, oregano, and rosemary (Benincasa et al., 2014; Enoch et al., 1970; Ombodi et al., 2012; Shiwakoti et al., 2016). To our knowledge, very limited studies on LT have been done on strawberry production with LT alone or including LT in HT (Singh et al., 2012; Siwek et al., 2009; Teresa Ariza et al., 2012). Here we report the effects of LT inside HT and planting dates on the season extension potential, plant growth, and yield of two day-neutral strawberries in North Carolina.

\section{Materials and Methods}

The study was conducted on the University Farm of North Carolina Agricultural and Technical State University in Greensboro, $\mathrm{NC}$ (lat. $36^{\circ} 04^{\prime} 09.8^{\prime \prime} \mathrm{N}$, long. $79^{\circ} 43^{\prime} 49.6^{\prime \prime}$ W, $228 \mathrm{~m}$ ) in USDA plant hardiness zone $7 \mathrm{~b}$. The high tunnels have Enon sandy loam soil. Summer cover crops sudangrass (Sorghum bicolor) and pearl millet (Pennisetum glaucum) were planted inside the high tunnel in previous seasons. The research was conducted from Sept. 2016 to May 2017 for the first year (2016-17) and repeated from Sept. 2017 to May 2018 for the second year (2017-18).

Table 3. Days after planting (DAP) for bloom (first, 50\%, and 75\%) and harvest (first, 50\%, and 75\%) in 2017-18.

\begin{tabular}{|c|c|c|c|c|c|c|}
\hline \multirow[b]{2}{*}{ Treatment } & \multicolumn{3}{|c|}{ Plants bloomed } & \multicolumn{3}{|c|}{ Plants harvested } \\
\hline & $\overline{\text { First bloom }}$ & $50 \%$ bloom & $75 \%$ bloom & First harvest & $50 \%$ harvest & $75 \%$ harvest \\
\hline $\mathrm{LT}^{\mathrm{z}}$ & 21 & 37 & 59 & 51 & 73 & 99 \\
\hline D1 & 20 & 37 & 57 & 47 & 64 & 87 \\
\hline D2 & 24 & 37 & 54 & 58 & 84 & 111 \\
\hline \multicolumn{7}{|l|}{ Cultivars (C) } \\
\hline \multicolumn{7}{|l|}{ Significance } \\
\hline $\mathrm{P}$ & NS & NS & NS & NS & NS & NS \\
\hline $\mathrm{D}$ & NS & NS & NS & 0.0002 & $<0.0001$ & 0.0238 \\
\hline $\mathrm{P} \times \mathrm{D}$ & NS & NS & NS & 0.0007 & NS & NS \\
\hline C & $<0.0001$ & $<0.0001$ & 0.0433 & $<0.0001$ & 0.0002 & NS \\
\hline $\mathrm{P} \times \mathrm{C}$ & NS & NS & NS & NS & NS & NS \\
\hline $\mathrm{D} \times \mathrm{C}$ & NS & $<0.0001$ & NS & 0.0185 & NS & NS \\
\hline
\end{tabular}

${ }^{\mathrm{z}} \mathrm{LT}=$ low tunnels, NLT $=$ no low tunnels, D1 $=9$ Sept., D2 $=10$ Oct., Ns $=$ not significant (at $P \geq 0.05$ ) per Fisher's least significant difference test. 
High tunnel and low tunnels. Two Quonsetstyle high tunnels of $29.3 \mathrm{~m}$ long, $9.1 \mathrm{~m}$ wide, and $1.5 \mathrm{~m}$ high (side walls) (Jaderloon ${ }^{\circledR}$, of north-south orientation, were used for

Table 4. Simple effects of planting dates (D) and cultivars (C) for days after planting (DAP) of $50 \%$ bloom and the first harvest in 2017-18.

\begin{tabular}{lccccc}
\hline & \multicolumn{2}{c}{$50 \%$ bloom } & & \multicolumn{2}{c}{ First harvest } \\
\cline { 2 - 3 } \cline { 5 - 6 } & $\mathrm{D}^{\mathrm{z}}$ & $\mathrm{D} 2$ & & $\mathrm{D} 1$ & $\mathrm{D} 2$ \\
\hline Albion & $24 \mathrm{~b}^{\mathrm{y}}$ & $31 \mathrm{~b}$ & & $44 \mathrm{~b}$ & $49 \mathrm{~b}$ \\
& $\mathrm{~b}^{\mathrm{x}}$ & $\mathrm{a}$ & & $\mathrm{a}$ & $\mathrm{a}$ \\
San Andreas & $50 \mathrm{a}$ & $43 \mathrm{a}$ & & $51 \mathrm{a}$ & $68 \mathrm{a}$ \\
& $\mathrm{a}$ & $\mathrm{b}$ & $\mathrm{b}$ & $\mathrm{a}$ \\
$\mathrm{D} \times \mathrm{C}(P$ value $)$ & $<0.0001$ & & 0.0185 & \\
\hline
\end{tabular}

${ }^{\mathrm{z}} \mathrm{DAP}=$ days after planting, D1 = 1 Sept., D2 $=29$ Sept.

${ }^{\mathrm{y}}$ Within each column of a category $(50 \%$ bloom and first harvest), values with a same letter are not significantly different at the 5\% level per Fisher's least significant difference test for cultivars (Albion vs. San Andreas).

${ }^{\mathrm{x}}$ Within each row of a category $(50 \%$ bloom and first harvest), values with a same letter are not significantly different at the 5\% level per Fisher's least significant difference test for planting dates (D1 vs. D2).

Table 5. Simple effects of protection methods (P) and planting dates (D) for days after planting

\begin{tabular}{lcc}
\hline & \multicolumn{2}{c}{ First harvest (DAP) } \\
\cline { 2 - 3 } & $\mathrm{D} 1$ & $\mathrm{D} 2$ \\
\hline $\mathrm{LT}^{\mathrm{z}}$ & $51 \mathrm{a}^{\mathrm{y}}$ & $52 \mathrm{~b}$ \\
$\mathrm{NLT}$ & $\mathrm{a}^{\mathrm{x}}$ & $\mathrm{a}$ \\
& $44 \mathrm{a}$ & $64 \mathrm{a}$ \\
$\mathrm{P} \times \mathrm{D}(P$ value $)$ & $\mathrm{b}$ & $\mathrm{a}$ \\
& & 0.0007
\end{tabular}

${ }^{\mathrm{z}} \mathrm{LT}=$ low tunnels, NLT $=$ no low tunnels, D1 $=9$ Sept., D2 $=10$ Oct.

${ }^{\mathrm{y}}$ Within each column, values with a same letter are not significantly different at the $5 \%$ level per Fisher's least significant difference test for protection method (LT vs. NLT).

${ }^{\mathrm{x}}$ Within each row, values with a same letter are not significantly different at the $5 \%$ level per Fisher's least significant difference test for planting dates (D1 vs. D2) The Greenhouse Company, Columbia, SC), (DAP) of the first harvest in 2017-18.

this study. The high tunnels were covered with $0.15-\mathrm{mm}$ greenhouse-grade polythene film and had about $267 \mathrm{~m}^{2}$ of total planting area for each tunnel. HT air temperatures were maintained at 21 to $24{ }^{\circ} \mathrm{C}$ by opening and closing the retractable side walls. In the winter, when the air temperature was $<13{ }^{\circ} \mathrm{C}$, the side walls were mostly closed, except for a 30- to 60-min opening in the afternoon to reduce humidity.

A LT kit is $30.5 \mathrm{~m}$ long, $0.7 \mathrm{~m}$ wide, and $0.8 \mathrm{~m}$ high (center) covered with $0.038-\mathrm{mm}$ clear plastic film perforated on both sides (Dubois Agrinovation, Quebec, Canada). To install LT, the steel hoops were anchored with galvanized steel stakes placed at $1.5 \mathrm{~m}$ apart on both sides of the hoops. Galvanized poles ( $0.6 \mathrm{~m}$ long) were used at both ends of the rows to anchor the plastics for LT. The hoops were covered with plastic films, tied on the end poles, and wrapped with 2.4- $\mathrm{m}$ long polyester bungee elastic cords. The LT were installed in late October inside the HT. The LT were closed most of the time, except when conducting data collection, harvesting, and other management activities. For extra frost protection during the winter months, all experimental plots were covered with nonwoven floating rowcovers of $42.5 \mathrm{~g} / \mathrm{yard}^{2}$ (Gro-Guar, Atmore Industries, Inc., Atmore, AL).

Plug production. Because plugs were not available from commercial nurseries for our planting time, we raised plugs in a greenhouse. Conventional runner tips of 'Albion' and 'San Andreas' were collected in mid-July from Norton Creek Farms (Cashiers, NC), stored at $4.4{ }^{\circ} \mathrm{C}$ and $75 \%$ to $80 \%$ relative humidity (RH) for 2 weeks (Durner et al., 2002; Poling, 1993). Before inserting these into growth media, excessive leaves and runner cords of tips were trimmed off, leaving two good leaves per tip. The resulting tips were inserted $6 \mathrm{~cm}$ deep in 50-cell trays containing a growing media of 1:1 ratio mixture of organic compost (Brooks Contractor, Goldston, NC) and Sunshine organic soil mix (Sun Gro Horticulture, Agawam, MA). The trays with tips were placed for $28 \mathrm{~d}$ on rolling benches inside the greenhouse.

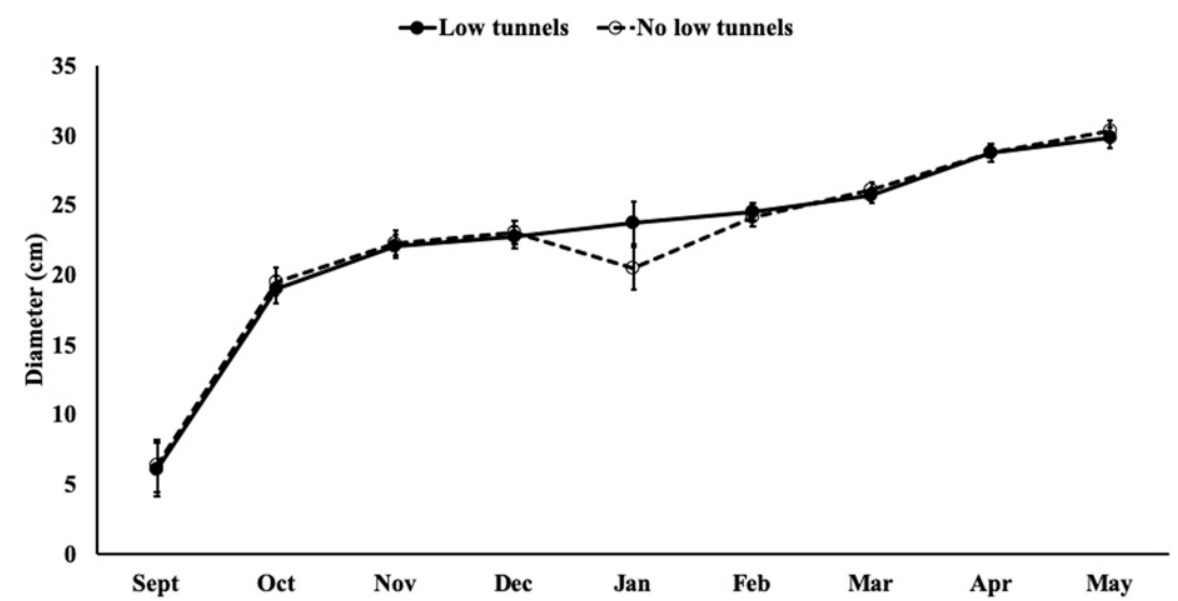

Fig. 1. Monthly canopy diameter $(\mathrm{cm})$ of strawberry plants with and without low tunnels inside high tunnels in 2017-18. Vertical bars denote the standard errors of mean values of the canopy diameter for plants with or without low tunnels.
The misting schedule of plugs was done according to the Southeast Regional Strawberry Plasticulture Production Guide (Poling, 1993).

Experimental design. A completely randomized design with three replications was conducted as a split-split plot $(2 \times 2 \times 2$ factorial) design. Protection methods (LT and NLT) were main plots (whole bed), planting dates (D1 and D2) were split plots ( $1 / 2$ bed), and cultivars (Albion and San Andreas) were split-split plots ( $1 / 4$ bed). Plants in each splitsplit plot were further divided into a harvest section (20 plants) and a biomass section (22 plants). A total of 1008 plants (42 plants per plot) were planted in all 24 split-split plots.

Field preparation, transplanting, and fertigation. High tunnel soil was tilled twice before applying preplant fertilizer and making raised beds. Based on the soil test results from the North Carolina Department of Agriculture and Consumer Services, Raleigh, $13.8 \mathrm{~kg} \mathrm{~N}, 2.4 \mathrm{~kg} \mathrm{~K}, 6 \mathrm{~kg} \mathrm{~S}$, and $0.14 \mathrm{~kg} \mathrm{~B}$ per acre were incorporated into the soil. Eight beds (along the length of the HT) measured at $25.5 \mathrm{~cm}$ high and $76 \mathrm{~cm}$ wide, $1.5 \mathrm{~m}$ spacing (bed center-to-center) were made inside each high tunnel. The beds were covered with 48inch $(122 \mathrm{~cm})$ wide, 1.25 -mil $(0.032 \mathrm{~mm})$ thick, embossed black plastic mulch (Berry Hill Irrigation, Buffalo Junction, VA). The six beds in the middle were used for this study, the two side beds were used for guard plants. One 8-mil drip tape of 12-inch $(30.5 \mathrm{~cm})$ emitter spacing, which has a capacity of $1.02 \mathrm{~L} / \mathrm{h}$ water, was placed in the middle of each bed (Toro Micro-Irrigation, El Cajon, CA).

Strawberry plugs were transplanted into the raised bed on 1 Sept. (D1) and 29 Sept. (D2) 2016 (the first year) and on 9 Sept. (D1) and 10 Oct. (D2) 2017 (the second year). The plugs were spaced at $30.5 \times 30.5 \mathrm{~cm}$ within and between the rows, with two rows per bed.

During the growing season, fish emulsion (5-1-1) was fertigated from late winter (February) to harvest (May) at the rate of $1.1 \mathrm{~kg}$ / week. About $25.5 \mathrm{~mm}$ of water was irrigated each week through drip tapes, up to four times a week, based on weather conditions.

Pest control. Over a growing season, dead leaves were pruned off as a preventive means to control pests (disease, insects, and spider mites). Plants were scouted weekly for pest incidence. When one two-spotted spider mite per leaf (in average) was noticed, predatory mites (Phytoseiulus persimilis) were released at the rate of 1.4 adult $/ \mathrm{ft}^{2}$ (Spidex, Koppert Biological System Inc., Howell, MI). In addition, Organic Materials Review Institute (OMRI) listed pesticide M-Pede (potassium salts of fatty acids), Trilogy (neem oil), Dipel (Bacillus thuringiensis), PFR-97 (Isaria fumosorosea), or PyGanic (pyrethrins) were applied based on the pests scouted.

Data collection. Biomass was measured monthly from October to May in both years. A pair of whole plants (including roots) from the biomass section of each plot were destructively harvested each month, cleaned, separated into different parts (leaves, runners, crown, flowers, fruits, and roots), dried 


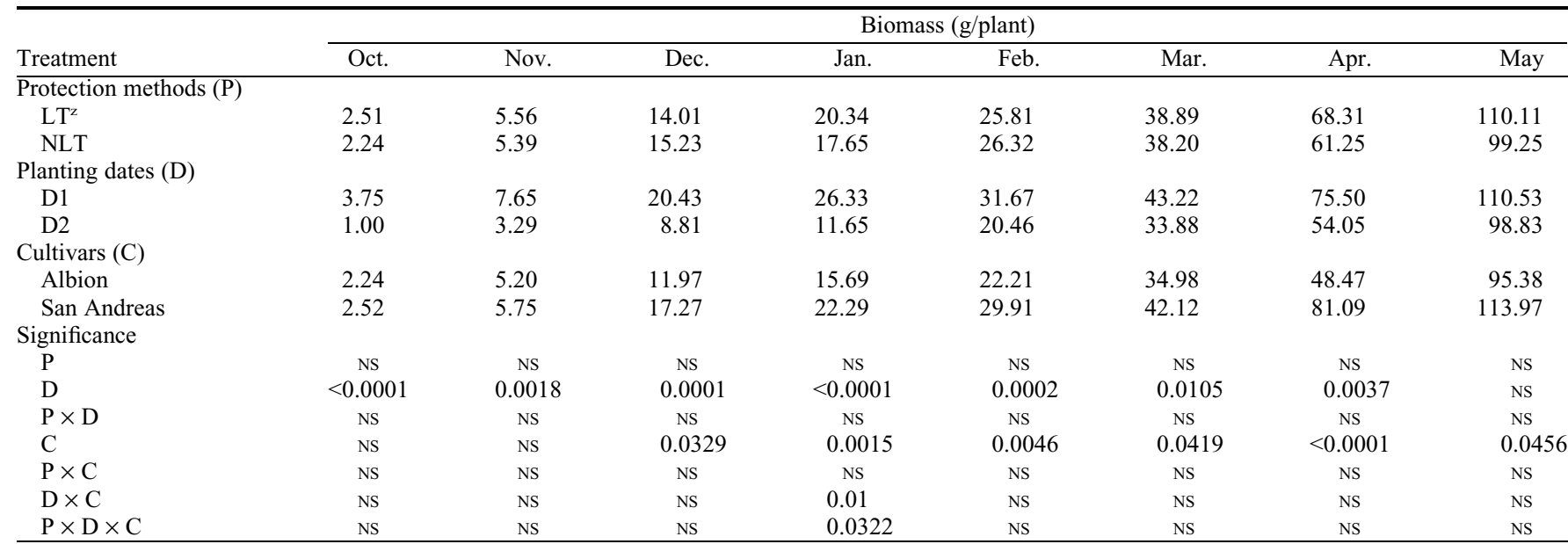

${ }_{\mathrm{z}} \mathrm{LT}=$ low tunnels, NLT= no low tunnels, D1 $=1$ Sept., D2 $=29$ Sept., Ns $=$ not significant (at $P \geq 0.05$ ) per Fisher's least significant difference test.

Table 7. Monthly biomass for 'San Andreas' in 2017-18.

\begin{tabular}{|c|c|c|c|c|c|c|c|c|c|}
\hline \multirow[b]{2}{*}{ Treatment } & \multicolumn{9}{|c|}{ Biomass (g/plant) } \\
\hline & Sept. & Oct. & Nov. & Dec. & Jan. & Feb. & Mar. & Apr. & May \\
\hline \multicolumn{10}{|c|}{ Protection methods (P) } \\
\hline $\mathrm{LT}^{\mathrm{z}}$ & 1.10 & 4.32 & 10.08 & 13.17 & 21.82 & 25.27 & 37.90 & 60.25 & 61.71 \\
\hline NLT & 0.89 & 4.27 & 9.12 & 16.24 & 20.11 & 21.53 & 33.62 & 51.26 & 76.54 \\
\hline$P$ value & NS & NS & NS & NS & NS & NS & NS & NS & NS \\
\hline \multicolumn{10}{|c|}{ Planting dates (D) } \\
\hline D1 & 1.99 & 5.74 & 14.19 & 19.01 & 27.55 & 29.82 & 43.13 & 64.37 & 80.06 \\
\hline D2 & $\mathrm{n} / \mathrm{a}$ & 2.85 & 5.00 & 10.40 & 14.38 & 16.98 & 28.39 & 47.14 & 58.19 \\
\hline$P$ value & $<0.0001$ & 0.0014 & 0.0058 & 0.0144 & 0.0124 & 0.0237 & 0.0486 & NS & 0.0422 \\
\hline $\mathrm{P} \times \mathrm{D}$ & NS & NS & NS & NS & NS & NS & NS & NS & NS \\
\hline
\end{tabular}

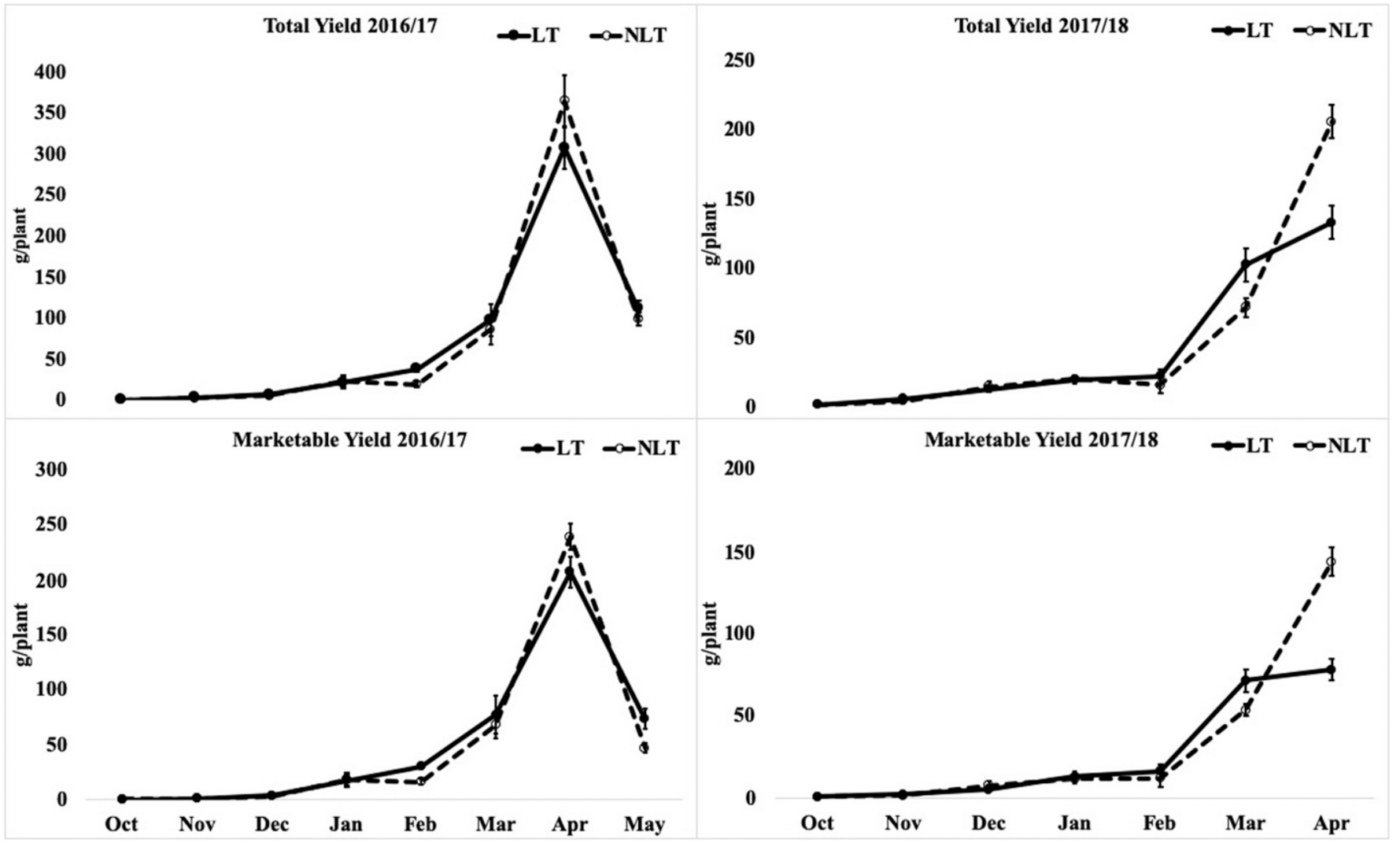

Fig. 2. Monthly marketable and total yield (g/plant) with low tunnels (LT) and without low tunnels (NLT). Vertical bars denote the standard errors of the mean values of the total and marketable yield for LT and NLT. 


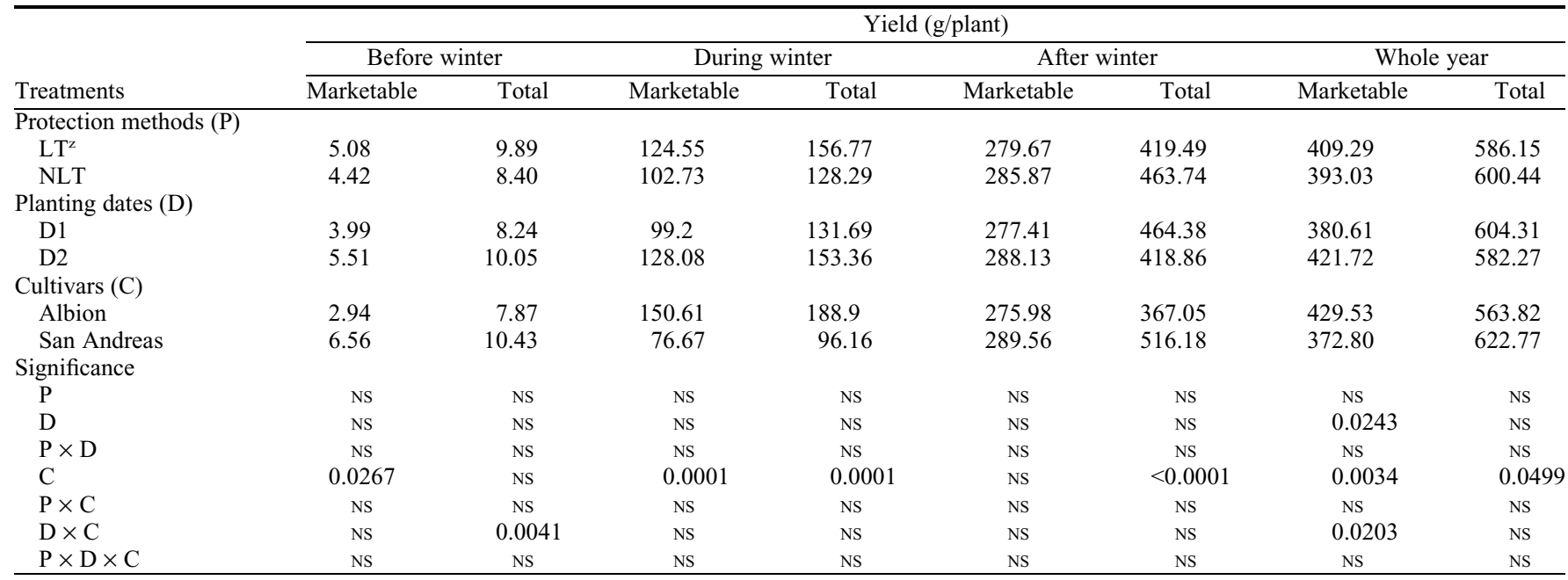

${ }^{\mathrm{z}} \mathrm{LT}=$ low tunnels, NLT $=$ no low tunnels, D1 $=1$ Sept., D2 $=29$ Sept., NS $=$ not significant (at $P \geq 0.05$ ) per Fisher's least significant difference test.

Table 9. Simple effects of planting dates (D) and cultivars (C) on the total marketable yield in 2016-17.

\begin{tabular}{lcc}
\hline & \multicolumn{2}{c}{ Marketable yield (whole season, $\mathrm{g} /$ plant $)$} \\
\cline { 2 - 4 } & $\mathrm{D}^{\mathrm{z}}$ & $\mathrm{D} 2$ \\
\hline Albion & $430.26 \mathrm{a}^{\mathrm{y}}$ & $428.80 \mathrm{a}$ \\
San Andreas & $\mathrm{a}^{\mathrm{x}}$ & $\mathrm{a}$ \\
$\mathrm{D} \times \mathrm{C}(P$ value $)$ & $330.95 \mathrm{~b}$ & $414.64 \mathrm{a}$ \\
$\mathrm{C}$ & $\mathrm{b}$ & $\mathrm{a}$ \\
\hline
\end{tabular}

${ }^{\mathrm{z}} \mathrm{D} 1=9$ Sept., $\mathrm{D} 2=10$ Oct.

${ }^{\mathrm{y}}$ Within each column, values with a same letter are not significantly different at the 5\% level per Fisher's least significant difference test for cultivars (Albion vs. San Andreas).

${ }^{\mathrm{x}}$ Within each row, values with a same letter are not significantly different at the $5 \%$ level per Fisher's least significant difference test for planting dates (D1 vs. D2).

in an oven at $70{ }^{\circ} \mathrm{C}$ for $7 \mathrm{~d}$ and weighed. Fruits (collected twice a week) and runners (collected weekly) were harvested and dried, then the dry weight was added to the biomass for each month.

Monthly canopy length and width from nine random plants of the harvest section of each plot were measured and averaged to get canopy diameter. The number of runners were counted from plants of both harvest and biomass sections of each plot at a 10-day interval. Harvest index (HI) and monthly resource allocation pattern of the plant were calculated according to Fernandez et al. (2001).

Bloom data were taken twice a week from 18 plants of the harvest section of each plot. The days after planting (DAP) of blooming were recorded from the harvest section of each plot when the first plant, $50 \%$ and $75 \%$ plants were flowered in a plot.

Harvest generally took place twice a week except during the peak harvest (April to May), when fruits were harvested three times a week. In the first year, DAP was recorded for the first harvest. In the second year, DAP was recorded for the first plant, $50 \%$ and $75 \%$ plants harvest in a plot. Harvested fruits were separated into marketable and unmarketable fruits based on physical damage, disease, and weight. Blemish-free fruit that weighed $>10 \mathrm{~g}$ (Fernandez et al., 2001; Rowley et al., 2011) or any fruit that is salable at farmers' markets are considered as marketable.
Statistical analysis. The analysis of variance was performed using the PROC MIXED procedure of SAS (V9.2C for Windows; SAS Institute, Cary, NC). The LSMEANS statement was used for comparisons of means of the different treatments using Fisher's least significant difference test. Significance was determined at the level of $P<0.05$.

\section{Result and Discussion}

Phenology. In the first year (2016-17), the LT did not affect DAP of the first bloom, 50\% bloom, and the first harvest. D2 promoted the $50 \%$ bloom by 2.5 months earlier than D1 (Table 1). 'Albion' reached the 50\% bloom 1 week earlier than 'San Andreas'. Interactions between planting dates (D) and cultivars (C) existed for the DAP of the first bloom and the first harvest (Table 1). Looking at the simple effects, 'Albion' of D2 reached the first bloom and harvest earlier by 17 and $6 \mathrm{~d}$, respectively, compared with that of D1. 'San Andreas' of D1 was harvested $13 \mathrm{~d}$ earlier than that of D2. For D2, 'Albion' reached the first bloom and the first harvest 11 and $16 \mathrm{~d}$ earlier than 'San Andreas' (Table 2).

In the second year (2017-18), the LT inside the high tunnels also did not affect blooming and the DAP of the first, $50 \%$ harvest, and $75 \%$ harvest (Table 3). Interactions occurred between protection methods and planting dates for the first harvest and between planting dates and cultivars for the $50 \%$ bloom and first harvest. 'Albion' started the first bloom and reached the $75 \%$ bloom 13 and $17 \mathrm{~d}$ earlier than that of 'San Andreas'. 'Albion' also reached the 50\% and 75\% harvest 19 and $16 \mathrm{~d}$ earlier than that of 'San Andreas' (Table 3). 'Albion' of D1 reached $50 \%$ bloom and the first harvest 7 and $5 \mathrm{~d}$ earlier than that of D2 (Table 4). 'San Andreas' of D2 was $7 \mathrm{~d}$ earlier than that of D1 to reach the $50 \%$ bloom, although its first harvest was delayed by $17 \mathrm{~d}$ compared with that of D1. For both planting dates, 'Albion' reached the $50 \%$ bloom and had its first harvest 2 to 3 weeks and 1 to 3 weeks earlier than that of 'San Andreas' (Table 4). Although planting dates did not affect the DAP of the first harvest of plants in the LT, plants of D1 reached the first harvest $20 \mathrm{~d}$ earlier than plants of D2 in NLT (Table 5). For D1, LT plants had the first harvest delayed by one week compared with that of the NLT plants. For D2, the LT plants had the first harvest $12 \mathrm{~d}$ earlier than that of the NLT plants (Table 5). In the second year, the days for the blooming and harvest were earlier than those of the first year, which may be due to the warm weather from September to November.

Plant canopy and biomass. The size of plant canopy has shown a similar growth pattern in both years, thus only the second year results are presented here. The canopy size increased rapidly from September to November and remained almost the same from November to February in LT, with a slight decrease in canopy from December to January in NLT. After March, the canopy size increased rapidly until May. The LT did not affect the canopy size, although plants covered with LT were slightly bigger in January (Fig. 1). The plants of D1 had a bigger canopy compared with D2. 'San Andreas' had bigger canopy than 'Albion' (data not shown).

The monthly biomass of the first year is shown in Table 6. No difference between LT and NLT was found for each month's total biomass. D1 plants always had higher monthly total biomass than D2 plants, except 


\begin{tabular}{|c|c|c|c|c|c|c|c|c|}
\hline \multirow{2}{*}{ Treatment } & \multicolumn{8}{|c|}{ Yield (g/plant) } \\
\hline & \multicolumn{2}{|c|}{ Before winter } & \multicolumn{2}{|c|}{ During winter } & \multicolumn{2}{|c|}{ After winter } & \multicolumn{2}{|c|}{ Whole season } \\
\hline \multicolumn{9}{|c|}{ Protection methods (P) } \\
\hline NLT & 9.55 & 20.95 & 76.84 & 107.76 & 143.52 & 205.63 & 229.91 & 334.34 \\
\hline \multicolumn{9}{|c|}{ Planting dates (D) } \\
\hline D1 & 15.16 & 35.06 & 85.55 & 123.50 & 128.47 & 202.80 & 224.15 & 361.35 \\
\hline $\mathrm{D} 2$ & 2.01 & 6.09 & 92.17 & 128.48 & 93.10 & 135.60 & 192.31 & 270.17 \\
\hline San Andreas & 9.47 & 19.19 & 97.20 & 122.34 & 121.45 & 188.92 & 223.09 & 330.45 \\
\hline \multicolumn{9}{|l|}{ Significance } \\
\hline $\mathrm{P}$ & NS & NS & NS & NS & 0.005 & 0.0135 & 0.0241 & NS \\
\hline $\mathrm{D}$ & 0.0001 & $<0.0001$ & NS & NS & NS & 0.021 & NS & 0.0007 \\
\hline $\mathrm{P} \times \mathrm{D}$ & NS & NS & NS & NS & NS & NS & NS & NS \\
\hline $\mathrm{C}$ & NS & NS & NS & NS & NS & NS & NS & NS \\
\hline $\mathrm{P} \times \mathrm{C}$ & NS & NS & NS & NS & NS & NS & NS & NS \\
\hline
\end{tabular}

${ }^{\mathrm{z}} \mathrm{LT}=$ low tunnels, $\mathrm{NLT}=$ no low tunnels, $\mathrm{D} 1=9$ Sept., $\mathrm{D} 2=10$ Oct., $\mathrm{NS}=$ not significant (at $P \geq 0.05$ ) per Fisher's least significant difference test.

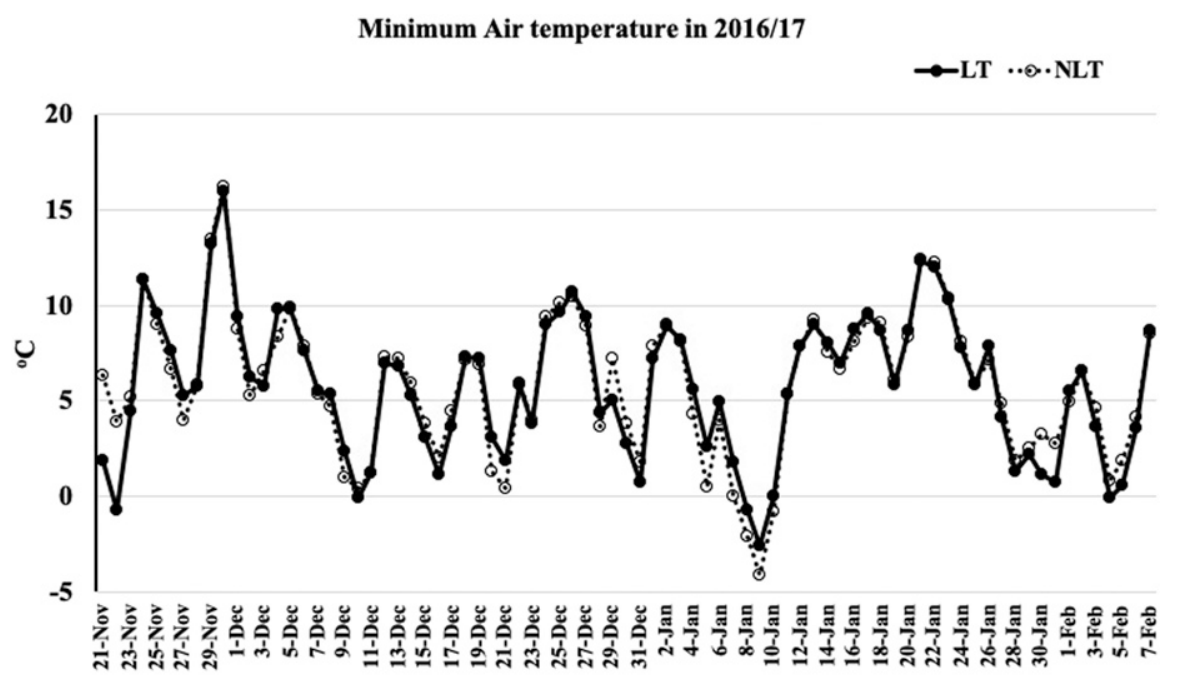

Minimum Air temperature in 2017/18

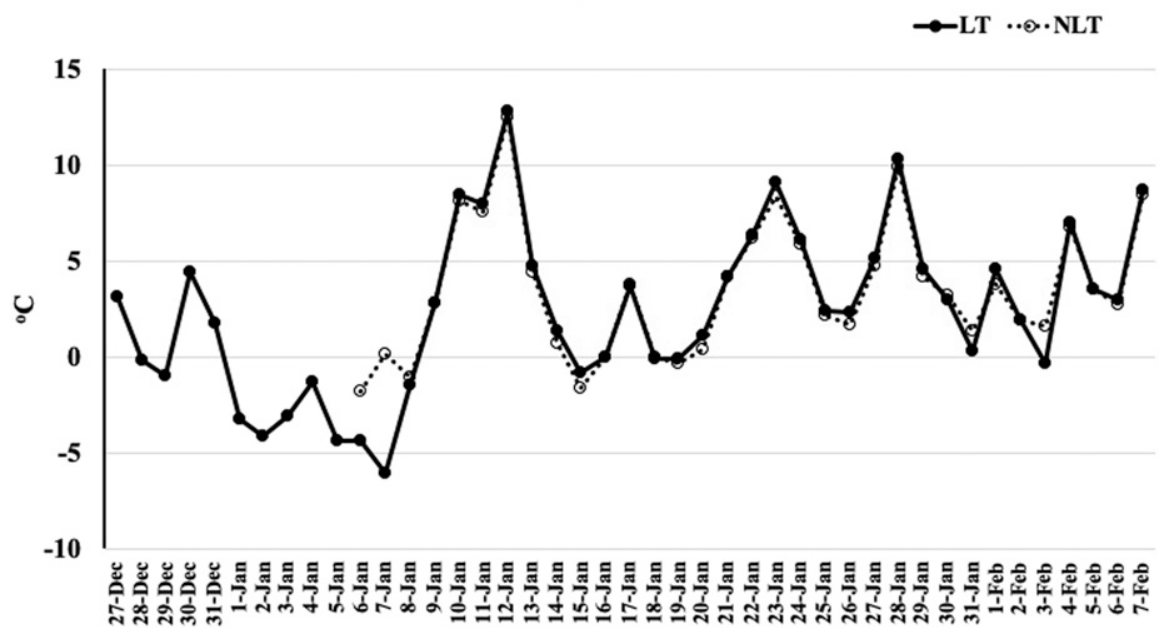

Fig. 3. Minimum air temperatures $\left({ }^{\circ} \mathrm{C}\right.$ ) inside the high tunnel (no low tunnels, NLT), and in low tunnels (LT) inside the high tunnel, during the two seasons indicated.

in May. 'Albion' had lower biomass than 'San Andreas' during and after the winter months. In the second year, only 'San Andreas' was sampled to reduce the amount of work. The LT did not promote plant growth, as shown by the similar biomass each month (Table 7). D1 plants also had greater biomass than D2 plants, except in
April (Table 7). Thus, biomass results were consistent for planting dates and protection method in both years.

Yield. The monthly marketable and total yield of LT and NLT for both years are shown in Fig. 2. The harvests took place from November to May, except for the second year when we did not harvest in May. From November to February, the yields were very low. Starting from March, yields increased rapidly and reached their peak in April. This trend is consistent with our previous study in North Carolina (Gu et al., 2017b). LT and NLT had similar yields from November to January, then LT had slightly higher yields compared with NLT in February, March and May (of the first year only). In April, yields were higher without LT (Fig. 2). This result might be due the higher yield in February (in the first year) or March (in the second year) inside the LT. Plants in LT may have used more resource in previous months compared with plants in NLT, leaving plants in LT fewer resources to use in April for fruit production.

Taking a further look at the yields, we grouped harvests into four periods: beforewinter (October to December), during-winter (January to March), after-winter (April and May), and the whole-season (Oct. to May). We believe this is important as winter berries always have higher prices. In the first year (Table 8), protection method and planting date did not affect the yields of each period (except for planting dates that affected the whole-season marketable yield). Yields of the two cultivars varied. During the winter, 'Albion' had higher marketable and total yields, but 'San Andreas' had higher total yields for the other periods. There were interactions among planting dates and cultivars for the total yield of before-winter and the total marketable yield of the entire season. The yields were very low before-winter, so the interactions were not further analyzed. The separation of the whole-season marketable yields by planting dates and cultivars is shown in Table 9. Basically, planting dates 
Table 11. Harvest index in both seasons (2016-17 and 2017-18).

\begin{tabular}{lcc}
\hline & \multicolumn{2}{c}{ Harvest index (\%) } \\
\cline { 2 - 3 } Treatment & $2016-17$ & $2017-18$ \\
\hline Protection methods (P) & 36 & 32 \\
$\quad$ LT $^{z}$ & 34 & 30 \\
NLT & & \\
Planting dates (D) & 29 & 28 \\
D1 & 41 & 34 \\
D2 & & \\
Significance & NS & NS \\
P & $<0.0001$ & 0.0481 \\
D & NS & NS \\
P $\times$ D &
\end{tabular}

${ }^{\mathrm{z}} \mathrm{LT}=$ low tunnels, NLT $=$ no low tunnels, D1 = 1 Sept. 2016 or 9 Sept. 2017, D2 = 29 Sept. 2016 or 10 Oct. 2017 , NS $=$ not significant (at $P \geq 0.05$ ) per Fisher's least significant difference test.

did not affect the whole-season marketable yield of 'Albion'; but it affected 'San Andrea", with D2 having a significantly higher marketable yield (414.6 g/plant) than D1 (330.9 g/plant). For D1, 'Albion' had a significantly higher marketable yield (430.3 g/plant) than 'San Andreas' (331 g/plant); but for D2, the difference was not significant. In the second year, no two-way or three-way interactions existed (Table 10). D1 plants had higher total yields before-winter, afterwinter, and the entire season (Table 10). The total yield and marketable yield of the second year, however, were lower than that of the first year. For example, the total marketable yield of 'Albion' was 429.5 and 193.4 $\mathrm{g} / \mathrm{plant}$ in the first and second year, respectively. The reduced yield in the second year may be due to three reasons: 1) The severe winter weather in the second year, with repeated freezing temperatures, caused more flower damage. In the second year, freezing events (temperature $<0{ }^{\circ} \mathrm{C}$ ) occurred as many as three times of the first year. Also, freezing events occurred frequently in January of the second year that caused more frost damage to flowers (Fig. 3). 2) Lower fertility shows in the lower amount of $\mathrm{N}, \mathrm{Mg}, \mathrm{S}$, and $\mathrm{Zn}$ in plant tissue in April (data not shown). 3) Fruit harvest data were not taken in May (due to changes in personnel). In the first year of the study, no difference was found in the yield (before-winter, during-winter, after-winter, as well as the whole-season) of LT and NLT. In second year, however, NLT had higher yield (marketable and total yield) after-winter and had higher whole-season marketable yield, compared with those of LT.

Although previous research in high elevation has reported that LT inside HT increased the yield of day-neutral cultivars (Rowley et al., 2011), our research in North Carolina did not show that increase. Still, the total yield (586.2 g/plant) of the 'Albion' in this study was comparable to the total yield of the mid-February planted 'Albion' (531 $\mathrm{g} / \mathrm{plant}$ ) in Rowley et al.'s study in 2011. Our first-year result also agreed with their result in that 'Albion' had lower whole-season total yield when compared with other day-neutral cultivars. However, 'Albion' had higher yield in the during-winter season and whole- season's marketable yield for first planting date (D1). Moreover, in the second year of this study, no difference was found between 'Albion' and 'San Andreas' for yield (Tables 8-10). The relatively lower yield of 'Albion' compared with 'San Andreas' was also found in previous reports in both open field and LT (Lewers et al., 2017). However, the marketable yield of 'Albion' from the first year (429.53 g/plant) in our study (Table 8 ) was far below the marketable yield (1.02 $\mathrm{kg} / \mathrm{plant}$ ) in the study by Ballington et al. (2008). The total yield of both cultivars in this study was also lower than in a previous field LT study (Lewers et al., 2017), which had reported a total yield of 'Albion' and 'San Andreas' ranging from 0.95 to 1.23 $\mathrm{kg} / \mathrm{plant}$ and 1.15 to $1.42 \mathrm{~kg} / \mathrm{plant}$, respectively. The difference in planting dates, harvesting seasons, and harvest durations along with production systems (organic vs. conventional, high tunnel vs. open field) would explain the yield differences.

Harvest index. Harvest index is the ratio of the dry weight of fruit to the total dry weight of the whole plant (Fernandez et al., 2001). In both seasons, the HI of LT and NLT had no significant difference (Table 11), meaning that the protection methods did not affect the plant's efficiency to allocate resource toward fruit. Plants of D2 had higher $\mathrm{HI}$ than that of D1, which indicates that plants of D2 were more efficient for allocating resources toward fruit.

In conclusion, LT inside HT did not significantly improve plant growth, early harvest, and yield, although their first harvest was 1 week earlier than the HT alone. Planting dates and cultivars affected phenology and yield with inconsistent effects in this 2 -year study. Cultivars may be the most important factor for organic strawberry production in HT. 'Albion' had earlier harvest and blooming dates than 'San Andreas'. Albion planted in D1 also had higher marketable yield. We propose to plant 'Albion' for the high tunnel production system aiming at slightly earlier yield during winter season. 'San Andrea' can be a cultivar of choice for high full-season yield. We also suggest removal of low tunnel after March, which may result in higher yields, although this needs to be explored in future research. More research is also needed in planting dates as well as cultivar selections for organic strawberry production in high tunnels.

\section{Literature Cited}

Anderson, H.C. 2018. Evaluating low tunnel plastics for day-neutral strawberry (Fragaria $\times$ ananassa Duchesne) production in Minnesota. MS thesis, Univ. of Minnesota, St. Paul, MN.

Ballington, J.R., B. Poling, and K. Olive. 2008. Day-neutral strawberry production for season extension in the midsouth. HortScience 43:1982 1986.

Benincasa, P., A. Massoli, L. Polegri, L. Concezzi, A. Onofri, and F. Tei. 2014. Optimising the use of plastic protective covers in field grown melon on a farm scale. Ital. J. Agron. 9(1):8-14.
Bomford, M., A. Silvernail, and B. Geier. 2007. Season extension with high tunnels in Kentucky. HortScience 42:988 (abstr.).

Bumgarner, N.R., M.A. Bennett, P.P. Ling, R.W. Mullen, and M.D. Kleinhenz. 2012. Active and passive zonal heating creates distinct microclimates and influences spring- and fall-time lettuce growth in Ohio. HortTechnology 22:228-236.

Carey, E.E., L. Jett, W.J. Lamont, T.T. Nennich, M.D. Orzolek, and K.A. Williams. 2009. Horticultural crop production in high tunnels in the United States: A snapshot. HortTechnology 19:37-43.

Chandler, C.K., E.E. Albregts, and C.M. Howard. 1991. Planting date affects early season strawberry production in west central Florida. Proc. Florida State Hort. Soc. 104:227-228.

Conti, S., G. Villari, S. Faugno, G. Melchionna, S. Somma, and G. Caruso. 2014. Effects of organic vs. conventional farming system on yield and quality of strawberry grown as an annual or biennial crop in southern Italy. Scientia Hort. 180:63-71.

Crecente-Campo, J., M. Nunes-Damaceno, M.A. Romero-Rodriguez, and M.L. Vazquez-Oderiz. 2012. Color, anthocyanin pigment, ascorbic acid and total phenolic compound determination in organic versus conventional strawberries ( $\mathrm{Fra}$ garia $x$ ananassa Duch, cv Selva). J. Food Compos. Anal. 28(1):23-30.

Durner, E.F., E.B. Poling, and J.L. Mass. 2002. Recent advances in strawberry plug transplant technology. HortTechnology 12:545-550.

Enoch, H., I. Rylski, and Y. Samish. 1970. $\mathrm{CO}_{2}$ enrichment to cucumber, lettuce and sweet pepper plants grown in low plastic tunnels in a subtropical climate. Isr. J. Agr. Res. 20(2):6369.

Esitken, A., H.E. Yildiz, S. Ercisli, M.F. Donmez, M. Turan, and A. Gunes. 2010. Effects of plant growth promoting bacteria (PGPB) on yield, growth and nutrient contents of organically grown strawberry. Scientia Hort. 124(1):6266.

Fernandez, G.E., L.M. Butler, and F.J. Louws. 2001 Strawberry growth and development in an annual plasticulture system. HortScience 36:12191223.

Gu, S., J.E. Beck, and J.A. Moore. 2017a. Characterizing high tunnel microclimate in hardiness zones $7 \& 8$ of North Carolina. Proceedings of the 7th National Small Farm Conference, p. 29-34.

Gu, S., W. Guan, and J.E. Beck. 2017b. Strawberry cultivar evaluation under high-tunnel and organic management in North Carolina. HortTechnology 27:84-92.

Jenni, S., I. Gamache, J.C. Côté, and K.A. Stewart. 2006. Plastic mulches and low tunnels to reduce bolting and increase marketable yield of early celery. J. Veg. Sci. 12(2):57-73.

Kadir, S., E. Carey, and S. Ennahli. 2006. Influence of high tunnel and field conditions on strawberry growth and development. HortScience 41:329-335.

Khalil, H.A. and S.M. Hassan. 2015. Ascorbic acid, $\beta$-carotene, total phenolic compound and microbiological quality of organic and conventional citrus and strawberry grown in Egypt. Afr. J. Biotechnol. 14(4):272-277.

Knewtson, S.J.B., E.E. Carey, and M.B. Kirkham. 2010. Management practices of growers using high tunnels in the central great plains of the United States. HortTechnology 20:639-645.

Lamont, W.J. 2005. Plastics: Modifying the microclimate for the production of vegetable crops. HortTechnology 15:477-481. 
Lamont, W.J. 2009. Overview of the use of high tunnels worldwide. Hort Technology 19:25-29.

Lewers, K.S., D.H. Fleisher, and C.S.T. Daughtry. 2017. Low tunnels as a strawberry breeding tool and season-extending production system. Intl. J. Fruit Sci. 17(3):233-258.

Ombodi, A., E. Kemenczei, T. Kassai, and J. Dimeny. 2012. Effect of different low tunnel covers on temperature conditions and development of sweet pepper. Proc. Intl. Soc. Hort. Sci. 936:347-354.

Orzolek, M.D., W. Lamont, and L. White. 2004. Promising horticultural crops for production in high tunnels in the mid-Atlantic area of the United States. Proc. Intl. Soc. Hort. Sci. 633:453-458.

Poling, E.B. 1993. Strawberry plasticulture in North Carolina: II, Preplant, planting, and postplant considerations for growing 'Chandler' strawberry on black plastic mulch. HortTechnology 3:383-393.

Reganold, J.P., P.K. Andrews, J.R. Reeve, L. Carpenter-Boggs, C.W. Schadt, J.R. Alldredge, C.F. Ross, N.M. Davies, and J. Zhou. 2010. Fruit and soil quality of organic and conventional strawberry agroecosystems. PLoS One 5(9):e12346.

Reitmeier, C. and G. Nonnecke. 1991. Objective and sensory evaluation of fresh fruit of day-neutral strawberry cultivars. HortScience 26:843-845.

Rogers, M.A. and A.L. Wszelaki. 2012. Influence of high tunnel production and planting date on yield, growth, and early blight development on organically grown heirloom and hybrid tomato. HortTechnology 22:452-462.

Rowley, D., B.L. Black, D. Drost, and D. Feuz. 2010. Early-season extension using June-bearing 'Chandler' strawberry in high-elevation high tunnels. HortScience 45:1464-1469.

Rowley, D., B.L. Black, D. Drost, and D. Feuz. 2011. Late-season strawberry production using day-neutral cultivars in high-elevation high tunnels. HortScience 46:1480-1485.

Ruan, J., Y.H. Lee, S.J. Hong, and Y.R. Yeoung. 2013. Sugar and organic acid contents of dayneutral and ever-bearing strawberry cultivars in high-elevation for summer and autumn fruit production in Korea. Hort. Environ. Biotechnol. 54(3):214-222.

Ruan, J., Y.R. Yeoung, and K.D. Larson. 2011. Influence of cultivar, planting date, and planting material on yield of day-neutral strawberry cultivars in highland areas of Korea. Hort. Environ. Biotechnol. 52(6):567-575.

Shiwakoti, S., V.D. Zheljazkov, V. Schlegel, and C.L. Cantrell. 2016. Growing spearmint, thyme, oregano, and rosemary in northern Wyoming using plastic tunnels. Ind. Crops Prod. 94:251258.

Singh, A., A. Syndor, B.C. Deka, R.K. Singh, and R.K. Patel. 2012. The effect of microclimate inside low tunnels on off-season production of strawberry (Fragaria $x$ ananassa Duch.). Scientia Hort. 144:36-41.

Siwek, P., R. Wojciechowska, A. Libik, and A. Kalisz. 2009. The effect of different kind of polyethylene film used as a low tunnel cover on celery yield and stalk quality. Agr. Uni. Kraków, Poland Veg. Crops Res. Bul. 70.

Sønsteby, A. and O.M. Heide. 2007. Long-day control of flowering in everbearing strawberries. J. Hort. Sci. Biotechnol. 82(6):875884.

Tabatabaie, S.M.H. and G.S. Murthy. 2016. Cradle to farm gate life cycle assessment of strawberry production in the United States. J. Clean. Prod. 127:548-554.

Teresa Ariza, M., C. Soria, J. Jesus MedinaMinguez, and E. Martinez-Ferri. 2012. Incidence of misshapen fruits in strawberry plants grown under tunnels is affected by cultivar, planting date, pollination, and low temperatures. HortScience 47:1569-1573.

Tudor, V., A. Asănică, and T. Neagu. 2014. First results of some day-neutral strawberry cultivars behavior in the Bucharest area conditions. Uni. Agron. Sci. and Veterinary Medicine of Bucharest 58:101-106.

USDA-AMS. 2018. National retail report: Specialty crops. U.S. Dept. Agr., Washington, D.C.

USDA-ERS. 2019. U.S. monthly average retail price: Fresh and processed fruits (U.S. city average). U.S. Dept. Agr., Washington, D.C. 19 Nov. 2019. <https://data.ers.usda.gov>.

USDA-NASS. 2017. Certified organic survey 2016 summary. U.S. Dept. Agr., Washington, D.C.

USDA-NASS. 2018. 2018 State agriculture overview; North Carolina. U.S. Dept. Agr., Washington, D.C.

Vocìa, S., N. Dobričevicì, M. Skendrovicì Babojelicì, J. Družicì, B. Duralija, and J. Levačicì. 2007. Differences in fruit quality of strawberry cv. Elsanta depending on cultivation system and harvest time. ACS Agr. Conspec. Sci. 72(4):285-288.

Waterer, D. 2003. Yields and economics of high tunnels for production of warm-season vegetable crops. Hort Technology 13:339-343.

Wien, H.C. 2009. Microenvironmental variations within the high tunnel. HortScience 44:235238.

Xiao, C.L., C.K. Chandler, J.F. Price, J.R. Duval, J.C. Mertely, and D.E. Legard. 2001. Comparison of epidemics of Botrytis fruit rot and powdery mildew of strawberry in large plastic tunnel and field production systems. Plant Dis. 85(8):901-909.

Zhao, X. and E.E. Carey. 2009. Summer production of lettuce, and microclimate in high tunnel and open field plots in Kansas. HortTechnology 19:113-119. 